\title{
Corumbataia britskii (Siluriformes: Loricariidae: Hypoptopomatinae) a new species from the upper Rio Paraná basin, Mato Grosso do Sul, Central Brazil
}

\author{
KATIANE M. FERREIRA ${ }^{1} \&$ ALEXANDRE C. RIBEIRO ${ }^{1,2}$ \\ ${ }^{1}$ Laboratório de Ictiologia de Ribeirão Preto (LIRP), Departamento de Biologia, FFCLRP-USP, Av. Bandeirantes, 3900, 14040-901, \\ Ribeirão Preto,SP, Brazil.E-mail: katiane@usp.br \\ ${ }^{2}$ Departamento de Zoologia, Instituto de Biociências, Universidade Estadual Paulista Júlio de Mesquita Filho (UNESP-Botucatu), \\ Caixa Postal 510,Botucatu, SP, Brazil.E-mail: acribeiro@click21.com.br
}

\begin{abstract}
A new Hypoptopomatinae, Corumbataia britskii, is described based on specimens recently collected in a tributary of the upper Rio Paraná basin, Mato Grosso do Sul State, Brazil. Corumbataia britskii differs from its congeners by having a more depressed head profile (vs. a more rounded head profile in C. cuestae and C. tocantinensis), by having a more developed and conspicuous tuft of enlarged odontodes on the tip of the supraoccipital (vs. its reduced condition found in C. cuestae and C. tocantinensis), and by heaving a partially enclosed arrector fossae (vs. an almost completely enclosed arrector fossae in $C$. cuestae and C. tocantinensis).
\end{abstract}

Key words. Siluriformes, Taxonomy, Upper Rio Paraná, South America, Neotropical Region

\section{Introduction}

The genus Corumbataia belongs to the Hypoptopomatinae, a group of small-sized armored catfishes composed by 17 genera and approximately 80 species (Schaefer, 2003; Ribeiro et al. 2005) distributed throughout cis-Andean South America from Venezuela to Northern Argentina (Schaefer, 1998).

Corumbataia was erected by Britski (1997) who defined the genus by the following combination of characters: exposed portion in the middle of the scapular bridge formed only by the coracoid (i.e., narrow cleithra which are covered by skin medially), compound hypurals 1 and 2 completely fused to the compound hypurals 3-5, atrophied maxillary barbel, and an infraorbital canal entering the infraorbital series via the pterotic-supracleithrum.

Corumbataia cuestae occurs in small streams of the Rio Tietê (upper Paraná basin), and C. tocantinensis occurs in the Rio Araguaia and Rio Tocantins. In this paper, we describe a third species of Corumbataia, from a headwater stream of the Rio Sucuriú, upper Paraná River Basin, Mato Grosso do Sul State, Central Brazil.

\section{Material and methods}

Measurements follow Boeseman (1968), including anal width, folded dorsal-fin length, snout-opercle length (Armbruster \& Page, 1996) and preanal length (Ribeiro et al. 2005). Plate counts and nomenclature follow the schemes of serial homology proposed by Schaefer (1997). Meristic data follow Bockmann \& Ribeiro (2003). Vertebral counts included all vertebrae (including the first five vertebrae modified into Weberian Apparatus), with the compound caudal centrum (PU1+U1) (Lundberg \& Baskin, 1969) counted as a single element. All 
morphometric and meristic data, including premaxillary and dentary teeth counts, were taken from the left side of the specimens.

Osteological terminology follows Schaefer (1997). Osteological examination and plate counts were performed on specimens cleared and stained (c\&s) according to the procedure of Taylor \& Van Dyke (1985).

Institutional abbreviations are as follows: LIRP (Laboratório de Ictiologia de Ribeirão Preto, Departamento de Biologia da FFCLRP, Universidade de São Paulo, Ribeirão Preto, Brazil) and LBP (Laboratório de Biologia de Peixes, Departamento de Morfologia, Instituto de Biociências-UNESP, Botucatu, Brazil).

\section{Corumbataia britskii, new species}

Fig. 1

Holotype. LIRP 5884, 26.0 mm SL, Brazil, State of Mato Grosso do Sul, Chapadão do Sul, Córrego Pedra Azul (19¹2'15'S 5243'55'W), Rio Sucuriú, upper Rio Paraná basin (Fig. 2), 10 October 2003, K.M. Ferreira, R.Campos-da-Paz \& E. Sá.

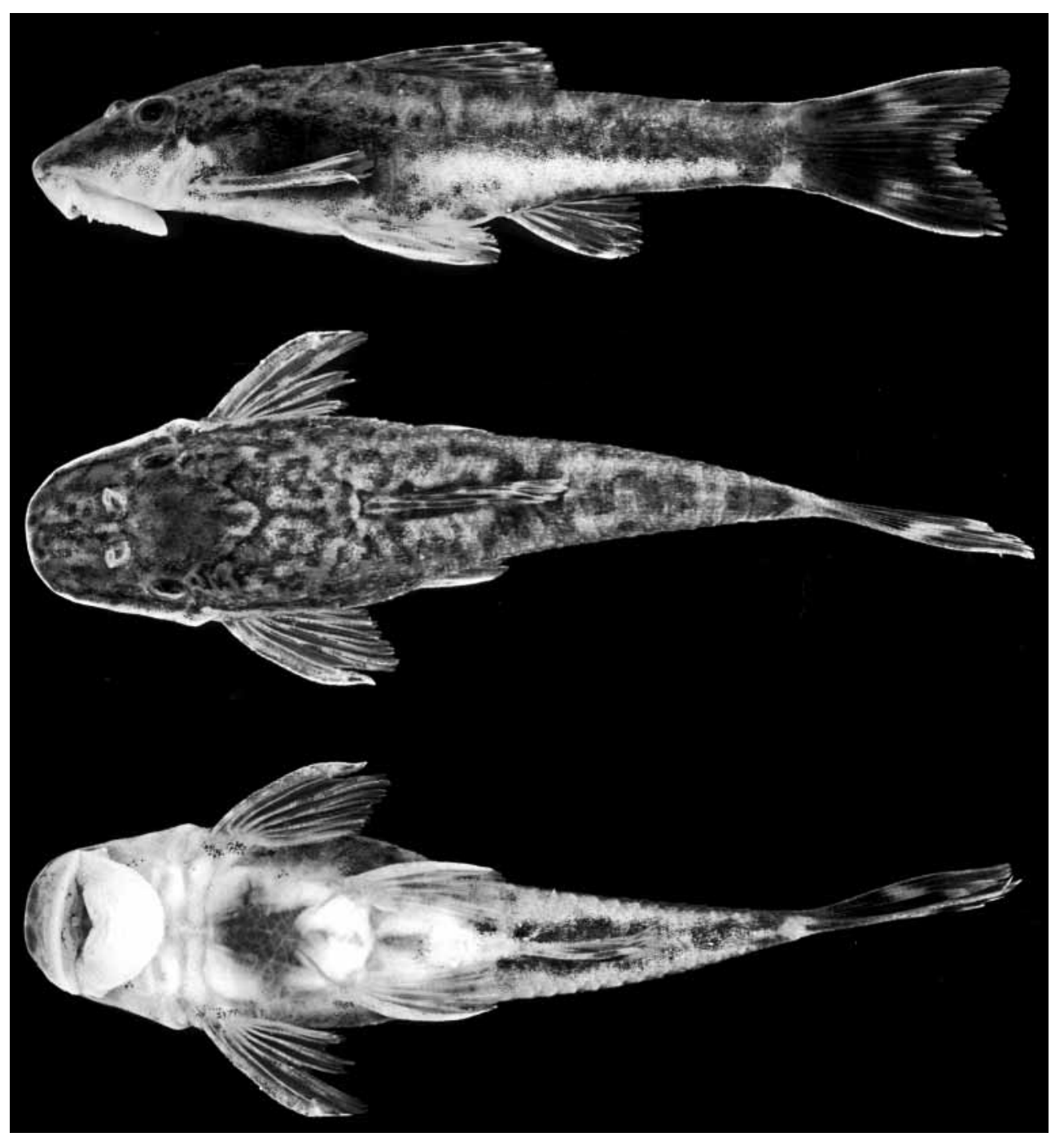

FIGURE 1. Lateral, dorsal and ventral views of holotype of Corumbataia britskii, LIRP 5884, $26.0 \mathrm{~mm}$ SL.

Paratypes. LIRP 4937, 5, 13.3-27.0 mm SL (2, 19.7-24.4 mm SL, c\&s), as the holotype. All from Brazil, Mato Grosso do Sul State, Chapadão do Sul, Rio Sucuriú, upper Rio Paraná basin: LIRP 5897 (2, 17.0-23.6 mm SL, c\&s), Córrego Pedra Azul (19¹2’15”S 5243’55”W), 23 August 2006, A.C. Ribeiro, M. Carvalho \& 


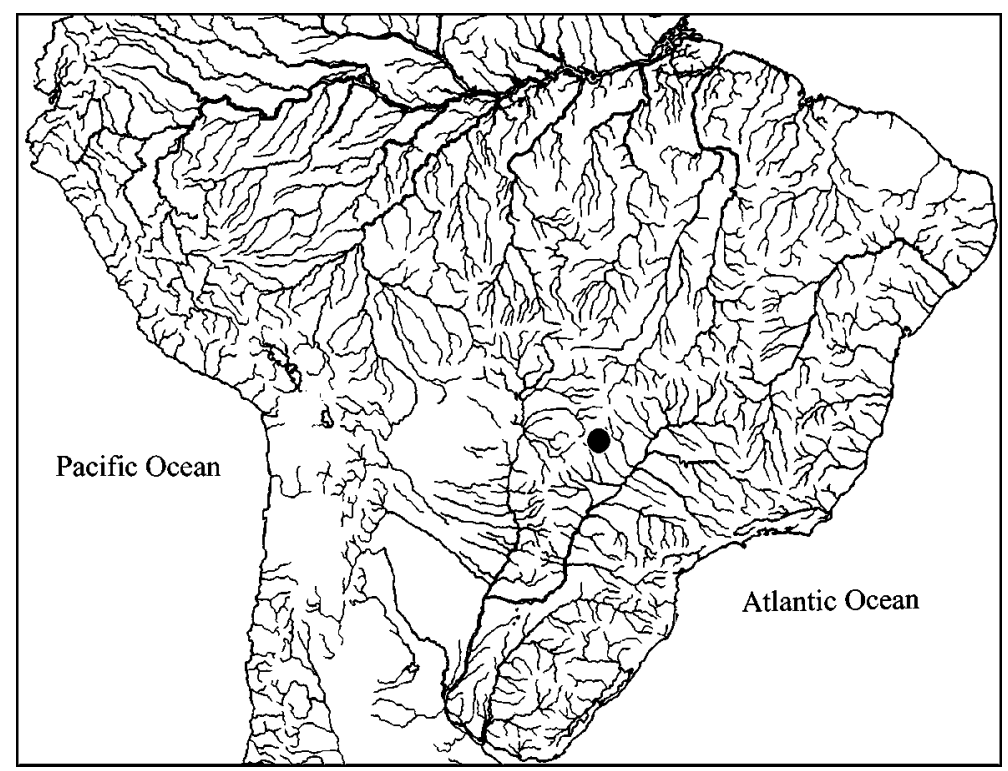

FIGURE 2. Type locality of Corumbataia britskii. Córrego Pedra Azul (19¹2'15”'S 5243'55”'W), Rio Sucuriú, upper Rio Paraná basin, Central Brazil.

Diagnosis. Corumbataia britskii differs from congeners by having a more depressed head profile (vs. more rounded in C. cuestae and C. tocantinensis) (Fig. 3), by having a more developed and conspicuous tuft of enlarged odontodes on the tip of the supraoccipital (vs. its reduced condition found in C. cuestae and $C$. tocantinensis) (Fig. 3), and by heaving a partially enclosed arrector fossae (vs. an almost completely enclosed arrector fossae in C. cuestae and C. tocantinensis) (Fig. 4).

Description. Morphometric and meristic data given in Tables 1 and 2, respectively. Dorsal profile of the body convex from snout tip to dorsal-fin origin; slightly concave at dorsal-fin base; straight from end of dorsal-fin base to caudal-fin origin. Ventral profile of the body straight from the snout tip to anus; straight at analfin base; straight from end of anal-fin base to caudal-fin origin. Greatest body depth at dorsal-fin origin; least body depth at caudal peduncle. Greatest body width at opercular or cleithral regions. Body progressively narrowing caudally from cleithrum. Head rounded anteriorly in dorsal view; eyes dorsolaterally positioned. Oral disk slightly elliptical, narrowing posteriorly. Anterior oral disk lobe covered by papilla of about same size. Posterior disk lobe covered by papilla which decrease in size posteriorly. Maxillary barbel atrophied. Compound pterotic-supracleithrum-posttemporal with small perforations along its median and inferior margins.

Body entirely covered by plates, except on rostrum, region overlying opening of swim bladder capsule, around anus, and in pectoral-, pelvic- and anal-fin insertions. Scapular bridge exposed and covered by odontodes. Abdomen in adult specimens covered with small plates which are absent in young specimens. Body plates completely covered by odontodes. Larger odontodes neighboring the supraoccipital bone. Lateral line interrupted by gaps in middle region and in caudal peduncle in a young c\&s specimen, but not interrupted in larger specimens.

Dorsal-fin origin located posteriorly to vertical through pelvic-fin origin. Adpressed pectoral fin extending over the pelvic-fin origin. Tip of pelvic fin reaching anal-fin origin in males and shorter in females.

Color in alcohol. Dark brown coloration on dorsal and lateral regions of body; ventral region yellowish and belly slight grayish. Numerous dark brown chromatophores distributed over head, forming a diffuse stripe from snout tip below eyes to posterior region of head. Chromatophores concentrated on dorsal- and anal-fin bases. Dark brown stripe extending from end of dorsal- to caudal-fin origin. Large diffuse dark brown midlat- 
eral stripe from snout tip, crossing eyes, extending to caudal-fin base. Large ventral dark brown stripe from around urogenital papillae to caudal-fin origin. Abdomen mostly unpigmented. Three to four transverse darkbrown stripes on dorsal-fin. Unbranched rays of pectoral, pelvic and anal fins with several scattered, widespread chromatophores not arranged in stripes. Caudal-fin mostly dark-brown with two unpigmented round spots on caudal-fin lobes.

TABLE 1. Descriptive morphometrics of Corumbataia britskii. Values are given for the holotype (separately) and 14 paratypes. Hol. $=$ Holotype; $\mathrm{SD}=$ Standard Deviation .

\begin{tabular}{llllll}
\hline Character & Hol. & Minimum & Maximum & Mean & SD \\
\hline Standard length $(\mathrm{mm})$ & 26.0 & 13.3 & 27.0 & 21.4 & 3.4
\end{tabular}

Percents of standard length

Predorsal length

$\begin{array}{lllll}42.7 & 42.5 & 48.3 & 45.5 & 2.0 \\ 61.2 & 48.3 & 63.4 & 54.8 & 5.0 \\ 31.9 & 31.5 & 36.6 & 34.1 & 1.9 \\ 25.4 & 18.0 & 25.9 & 21.9 & 3.4 \\ 22.3 & 17.6 & 23.6 & 20.8 & 1.9 \\ 25.8 & 18.4 & 26.9 & 24.2 & 2.2 \\ 15.4 & 11.3 & 15.4 & 13.5 & 1.1 \\ 21.2 & 16.0 & 21.2 & 18.3 & 1.3 \\ 21.9 & 16.8 & 23.6 & 19.5 & 2.5 \\ 18.8 & 11.3 & 22.7 & 16.4 & 4.3 \\ 18.1 & 15.5 & 21.4 & 18.4 & 2.2 \\ 28.5 & 24.4 & 32.1 & 28.3 & 2.4 \\ 10.4 & 8.3 & 10.8 & 10.2 & 0.7 \\ 6.9 & 5.7 & 8.9 & 7.3 & 0.8 \\ 24.2 & 20.9 & 26.4 & 24.4 & 1.3\end{array}$

Preanal length

Head length

Cleithral width

Dorsal-fin spine length

Folded dorsal-fin length

Base of dorsal-fin length

Thorax length

Pectoral-fin spine length

Abdomen length

Pelvic-fin spine length

Postanal length

Caudal-peduncle depth

Anal width

Snout-opercle length

$24.2 \quad 20.9$

Percents of head length

Head width

$\begin{array}{lllll}76.6 & 63.9 & 78.4 & 72.8 & 4.0 \\ 99.5 & 92.5 & 107.2 & 100 & 5.2 \\ 39.5 & 34.8 & 44.9 & 38.0 & 2.7 \\ 43.3 & 32.8 & 43.3 & 38.9 & 2.9 \\ 14.3 & 13.5 & 19.8 & 16.7 & 2.2\end{array}$

Percents of cleithral width

Anal width

50.8

34.1

52.1

$43.8 \quad 5.8$

Ecological notes. The new species was sampled in deforested areas in moderate to fast current streams. Corumbataia britskii was sampled in association with aquatic macrophytes or in the submerged portion of marginal vegetation. In its gut contents were found filamentous blue-green algae, chlorophyts, diatoms and periderm.

Distribution. Known just from two streams, Córrego Pedra Azul (type locality) and Córrego Fazendinha (19 $12^{\prime} 15^{\prime \prime} \mathrm{S} 52^{\circ} 43$ '55"W and 19 $14^{\prime} 43^{\prime \prime} \mathrm{S} 52^{\circ} 39^{\prime} 11.2^{\prime \prime} \mathrm{W}$, respectively). Both streams are tributaries of the Rio Sucuriú, a right tributary of the upper Rio Paraná basin in the Mato Grosso do Sul State, Brazil. 
Etymology. Named after Dr. Heraldo A. Britski, Museu de Zoologia da Universidade de São Paulo (MZUSP), in recognition of his many contributions to our understanding of Hypoptopomatinae catfishes.
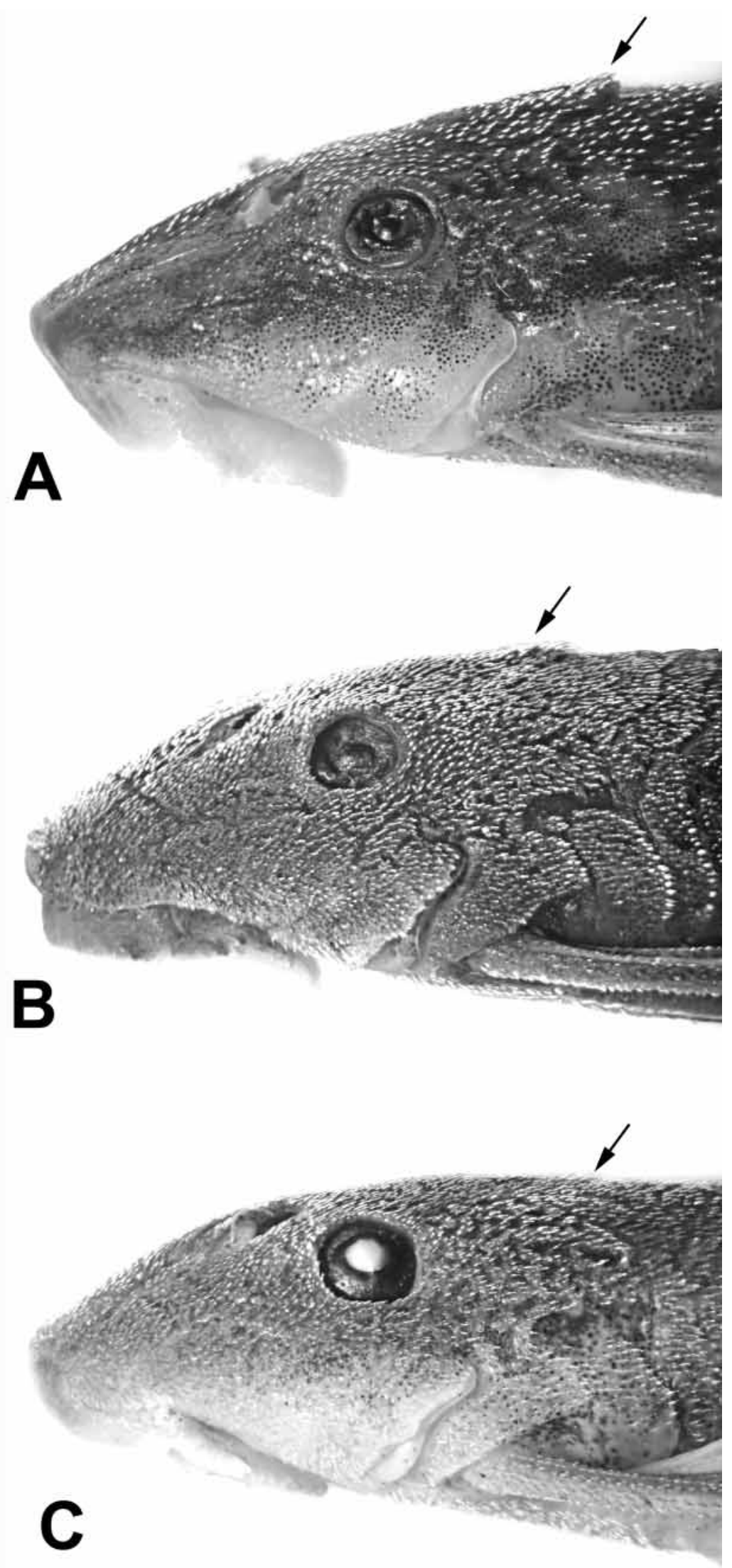

FIGURE 3. Lateral view of head of Corumbataia. (A) C. britskii, holotype, LIRP 5884, $26.0 \mathrm{~mm}$ SL; (B) C. cueatae, LIRP 2774, 29.5mm SL; (C) C. tocantinensis, LBP 1653, 26mm SL. Arrows indicate tip of supraoccipital. 
TABLE 2. Frequency distribution and summary of meristics for Corumbataia britskii. Holotype values are marked with an asterisk. Meristics marked with double asterisks were counted in c\&s specimens only.

\begin{tabular}{llll}
\hline Character & Frequency Distribution & Range & Mode \\
\hline Dorsal plates & $22(2) ; 23(4) ; 24(1)$ & $22-24$ & 23 \\
Mid-dorsal plates & $18(3) ; 19(1)$ & $18-19$ & 18 \\
Median plates & $19(3) ; 20(5) ; 21(4)$ & $19-21$ & 20 \\
anterior field plates & $8(1)$ & --- & --- \\
gap field plates & $6(1)$ & --- & --- \\
posterior field plates & $6(1)$ & --- & --- \\
Mid-ventral plates & $19(1) ; 20(2)$ & $19-20$ & 20 \\
Ventral plates & $18(1) ; 19(1) ; 20(4)$ & $18-20$ & 20 \\
& & & \\
Predorsal plates & $3(16)$ & --- & --- \\
Dorsal plates below dorsal-fin base & $5(16) ; 6 *(2)$ & $5-6$ & 5 \\
Dorsal plates between end of dorsal base and caudal-fin mem- & $12(16)$ & --- & --- \\
brane & & & \\
Ventral plates above anal-fin base & $3(12) ; 4(3)$ & $3-4$ & 3 \\
Ventral plates between end of anal base and caudal-fin mem-- & $9 *(14) ; 10(1)$ & $9-10$ & 9 \\
brane & & & \\
& & & \\
Dorsal-fin branched rays & 7 (all specimens) & --- & ---
\end{tabular}

\section{Discussion}

The phylogenetic relationships of Corumbataia is presently somewhat obscure. Schaefer $(1991,1997,1998)$ provided a phylogenetic analysis of the Hypoptopomatinae at the level of genera, recognizing it as a monophyletic unit and providing evidence for two natural subgroups within the subfamily, the tribes Otothyrini and Hypoptopomatini. Britski (1997), based on the set of characters presented by Schaefer (1991), included Corumbataia in the Otothyrini. This generic placement was not tested subsequently by Schaefer (1998), who did not include Corumbataia in his analysis. Recent papers (Ribeiro et al. 2002; Ribeiro et al. 2005) concerning the inclusion of new taxa within Schaefer's phylogenetic framework have not provided substantial changes in hypoptopomatine topology, and are in agreement with Schaefer's main conclusions. However, Gauger \& Buckup (2005), in including in a phylogenetic analysis two new species of Parotocinclus, several 
undescribed cascudinhos, as well as Corumbataia, concluded that Schaefer's Otothyrini is not monophyletic. These authors presented two alternative cladograms in their reanalysis of the Hypoptopomatine. In one of them, Corumbataia appears in a group that includes Microlepidogaster, Pseudotocinclus, Schizolecis, Pseudotothyris and Otothyris, all of which belonged to Schaefer's original concept of Otothyrini, corroborating the previous generic placement of Corumbataia made by Britski (1997).
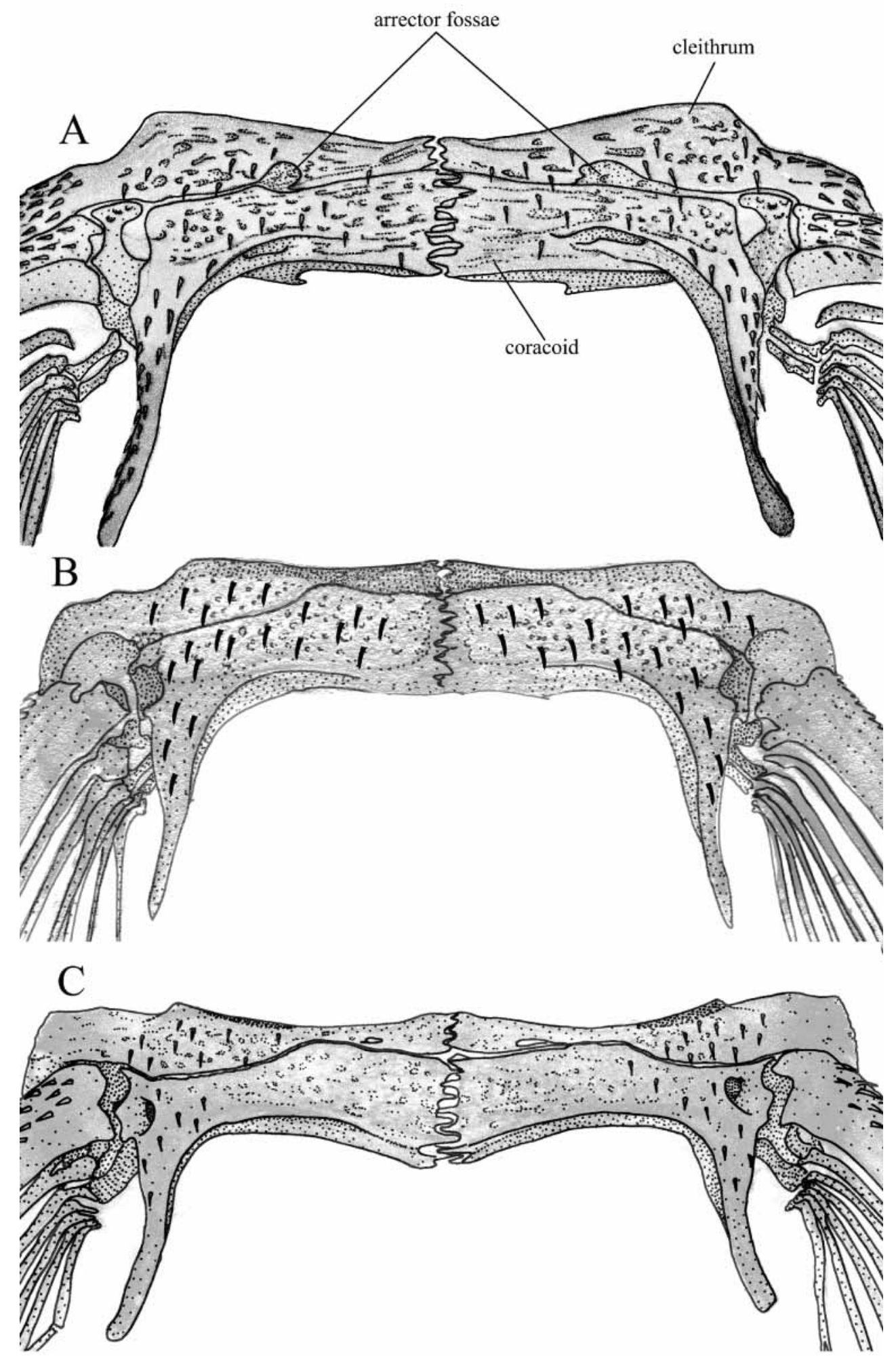

FIGURE 4. Ventral view of pectoral girdle of species of Corumbataia. (A) C. britskii; (B) C. cuestae; (C) C. tocantinensis. 

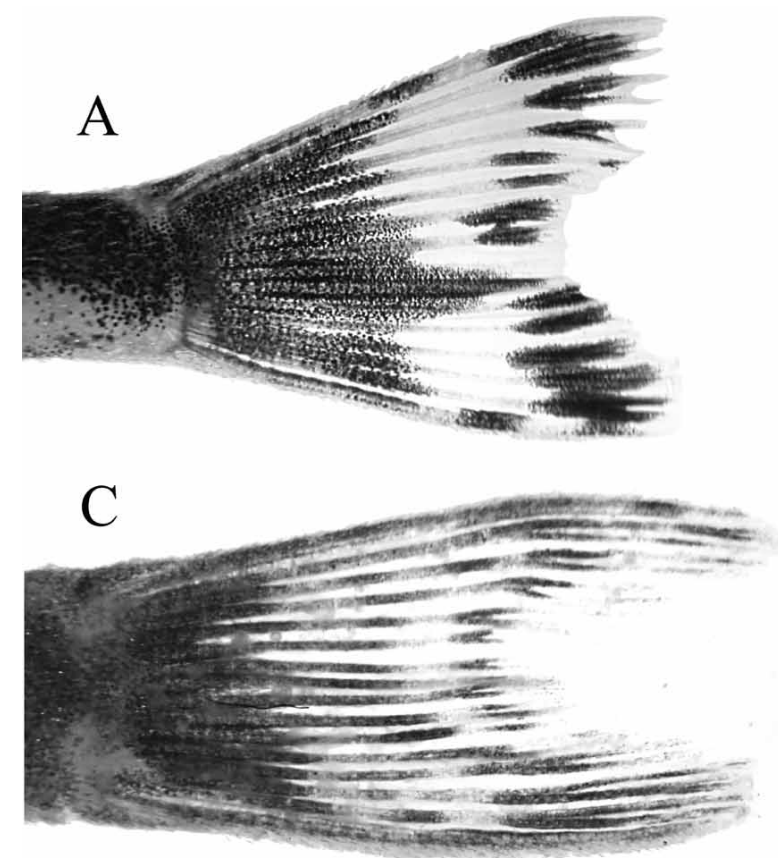
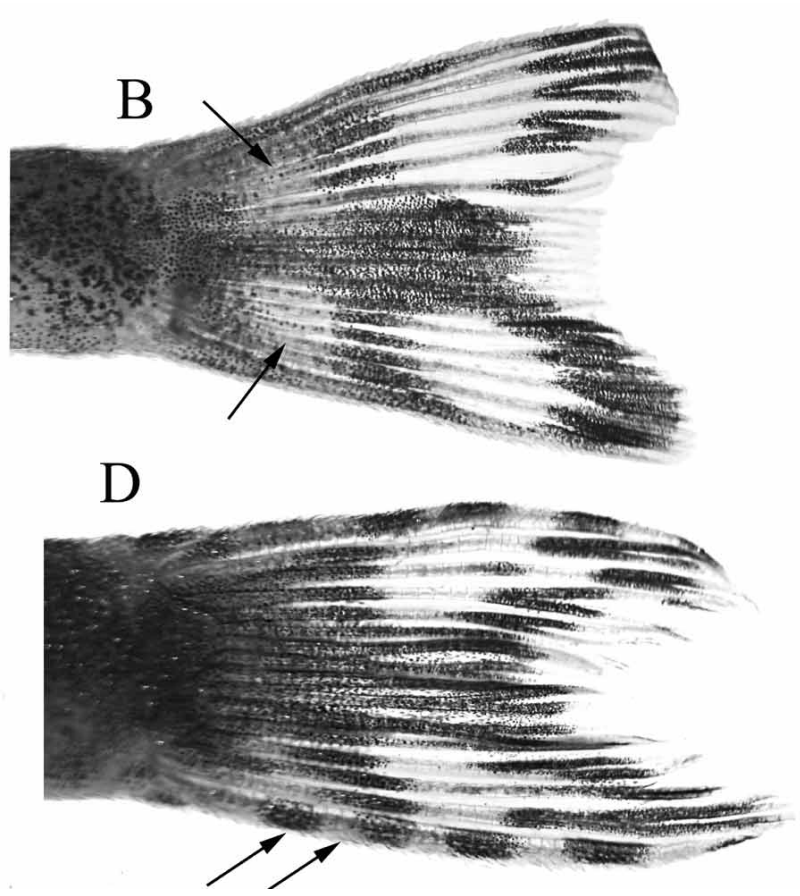

FIGURE 5. Lateral view of the caudal-fin indicating color patters in Corumbataia. (A) female of C. britskii; (B) male of C. britskii (arrows indicate clear caudal-fin blotches of males); (C) C. tocantinensis; (D) C. cuestae (arrows indicate stripes on unbranched caudal-fin rays).

We confirm in C. britskii all of the characters presented by Schaefer (1998) supporting the Otothyrini, except his character 35 (presence of a rostral plate with posterior notch articulating with mesethmoid Corumbataia presents a naked snout tip in which the rostral plate is absent), which are: presence of a deep metapterygoid channel (character 13, state 2), presence of a preopercle with a medially reflected ventral margin (character 18, state1), and presence of a ventrally expanded fourth infraorbital (character 37, state1).

According to Britski (1997), C. cuestae and C. tocantinensis should be differentiated only by counts of premaxillary and dentary teeth (23-28, 21-26 vs. 27-40, 26-39, respectively). However, Ferreira et al. (2006) also found citogenetic differences between $C$. cuestae and $C$. tocantinensis. Both species present biarmed chromosomes, but in $C$. cuestae the chromosomes are more metacentric while in $C$. tocantinensis they are more submetacentric. Furthermore, we observed that the two species can also be differentiated by color pattern, as the unbranched caudal-fin rays of $C$. britskii and $C$. tocantinensis lack the striped pattern present in $C$. custae (Fig. 5). Corumbataia tocantinensis and C. cuestae are more similar to each other in the morphology of the pectoral skeleton (Fig. 4). Both species share almost completely enclosed arrector fossae, which is partially opened in C. britskii. The lateral portions of the cleithra are wider in C. britskii than in the other two species.

Britski (1997) mentioned sexually dimorphic features for both C. cuestae and C. tocantinensis. Males differ from females by presenting a developed urogenital papillae posterior to the anus, a skin fold at the dorsal portion of the pelvic-fin spine, and a much longer pelvic-fin spine that extends over the first anal-fin ray. We confirmed all these characters in C. britskii and also observed that males of this species differ from females by having four white blotches on the caudal-fin, two at the dorsal lobe and two at the ventral lobe. Females, on the other hand, present only two white blotches, one on each lobe (Fig. 5A, B).

Comparative material. Corumbataia cuestae: MZUSP 51222, Holotype, São Paulo State Analândia, Cachoeira de Analândia, rio Corumbataí, H.A. Bristki, 27/07/1963; LIRP 2774, 169 (6 c\&s), Brazil, São 
Paulo State, São Pedro, Ribeirão da Ponta do Meio, Fazenda. Sta. M. da Ponta do Meio (22³3'27'S 47057'08'W), R.M.C. Castro, F.A. Bockmann, H.F. Santos, T.X. Abreu \& G.Z. Pelição, 29/05/2001. Corumbataia tocantinensis: MZUSP 51223, Holotype, Goiás State, rio Vermelho, Expedição DZ (H.A. Britski), 14/ 11/1966; LBP 1653, 27 (4 c\&s), Brazil, Goiás State, Rio Araguaia, Rio Vermelho (1555'1.5”'S 5007'43”'W), C. Oliveira, 15/12/2002; LBP 1972, Brazil, Goiás State, Rio Araguaia, Rio Vermelho (1554'10.9"S $50^{\circ} 06$ '53.8”W), C. Martins, 30/08/2003.

\section{Acknowledgments}

Murilo Carvalho and Otávio Froehlich helped during a field trip to collect additional specimens of our new species. Murilo Carvalho and Marcelo Britto provided suggestions that improved the manuscript. Cláudio Oliveira (LBP) is thanked for the loan of comparative material. This paper was financially supported by the “All Catfishes Species Inventory" Project (NSF DEB 0315963) that provided funding to visit collections. We also would like to thank our respective grants for financial support that allowed us to work on this project: Fundação de Amparo a Pesquisa do Estado de São Paulo (FAPESP 02/05464-0 to KMF) and Conselho Nacional de Desenvolvimento Científico e Tecnológico (CNPq 140488/04-9 to ACR).

\section{References}

Armbruster, J.W. \& Page, L.M. (1996) Redescription of Aphanotorulus (Teleostei: Loricariidae) with description of one new species, A. ammophilus, from the Río Orinoco basin. Copeia, 1996 (2), 379-389.

Bockmann F.A \& Ribeiro, A.C. (2003) Description of a new suckermouth armored catfish of the genus Pareiorhina (Siluriformes: Loricariidae), from southeastern Brazil. Ichthyological Exploration of Freshwaters, 14 (3), 231-242.

Boeseman, M. (1968) The genus Hypostomus Lacépède, 1803, and its Surinam representatives (Siluriformes, Loricariidae). Zoologische Verhandelingen, 99:1-89.

Britski, H.A. (1997) Descrição de um novo gênero de Hypoptopomatinae, com duas espécies novas (Siluriformes, Loricariidae). Papéis Avulsos de Zoologia, 40 (15), 231-255.

Ferreira, D.C., Chiachio, M.C., Takako, A.K., Andreata, A.A., Foresti, F. \& Oliveira, C. (2005) Comparative cytogenetics of nine species of Hypoptopomatinae (Teleostei: Siluriformes: Loricariidae): the importance of structural rearrangements in chromosome evolution. Caryologia, 58(4), 387-395.

Gauger, M.F.W. \& Buckup, P.A. (2005) Two new species of Hypoptopomatinae from the rio Paraíba do Sul basin, with comments on the monophyly of Parotocinclus and Otothyrini (Siluriformes: Loricariidae). Neotropical Ichthyology, 3(4), 509-518.

Lundberg, J.G. \& Baskin, J.N. (1969) The caudal skeleton of the catfishes, order Siluriformes. American Museum Novitates, 2398,1-49.

Ribeiro, A.C., Melo, A.L.A. \& Pereira, E.H.L. (2002) A New Species of Parotocinclus Eigenmann \& Eigenmann, 1889 (Siluriformes: Loricariidae) from the Rio São Francisco Basin, Southeastern Brazil. Ichthyological Exploration of Freshwaters, München, 13(3), 217-224.

Ribeiro, A.C., Carvalho, M. \& Melo, A.L.A. (2005) Description and relationships of Otothyropsis marapoama, a new genus and species of Hypoptopomatinae catfish (Siluriformes: Loricariidae) from rio Tietê basin, southeastern Brazil. Neotropical Ichthyology, 3(4), 489-498.

Schaefer, S.A. (1991) Phylogenetic analysis of the loricariid subfamily Hypoptopomatinae (Pisces: Siluroidei: Loricariidae), with comments on generic diagnoses and geographic distribution. Zoological Journal of the Linnaean Society, $102,1-41$.

Schaefer, S.A. (1997) The Neotropical Cascudinhos: Systematics and biogeography of the Otocinclus catfishes (Siluriformes: Loricariidae). Proceedings of the Academy of Natural Sciences of Philadelphia, 148,1-120.

Schaefer, S.A. (1998) Conflict and resolution: Impact of new taxa on phylogenetic studies of the neotropical cascudinhos (Siluriformes: Loricariidae). Pp. 375-400. In: L.R. Malabarba, R.E. Reis, R.P. Vari, C.A.S. Lucena, \& Z.M.S. Lucena (Eds.). Phylogeny and Classification of Neotropical Fishes. Porto Alegre, Edipucrs, 603p.

Schaefer, S.A. (2003) Loricariidae - Hypoptopomatinae (Armored catfishes). Pp. 321-329. In: R.E. Reis, S.O. Kullander \& C.J. Ferraris, Jr. (Eds.) Checklist of the Freshwater Fishes of South and Central America. Porto Alegre: Edipucrs, 729p. 
Taylor, W.R. \& Van Dyke, G.C. (1985) Revised procedures for staining and clearing small fishes and other vertebrates for bone and cartilage study. Cybium 9 (2), 107-119. 